\title{
E-Magazine Based on Augmented Reality Digestive as Digital Learning Media for Learning Interest
}

\author{
Zulfarina $^{1^{*}}$, Wan Syafii ${ }^{2}$, Deka Gusnia Putri ${ }^{3}$ (D) \\ 2,3 Biology Education PMIPA FKIP, Universitas Riau Indonesia \\ e-mail: zulfarina@lecturer.unri.ac.id
}

\section{A R T I CLE IN F O}

Article history:

Received June 27, 2021

Revised June 28, 2021

Accepted July 28, 2021

Available online August 25, 2021

Kata Kunci:

Minat, Augmented Reality, eMagazine

\section{Keywords:}

Interest, Augmented Reality, e-Magazine

DOI:

http://dx.doi.org/10.23887/jet.v5 i3.36110

\begin{abstract}
A B S T R A K
Kendala yang dihadapi dalam proses pembelajaran selama ini adalah rendahnya minat belajar siswa. Banyak faktor yang mempengaruhi minat belajar, salah satunya kurangnya variasi bahan ajar atau media pembelajaran yang digunakan guru di sekolah. Penggunaan augmented reality (AR) dalam pendidikan adalah sebuah topik penting penelitian walaupun penggunaannya masih dalam tahap awal. Tujuan dari penelitian ini adalah mengembangkan media pembelajaran, $e$ magazine berbasis AR untuk meningkatkan minat siswa belajar siswa SMA, pada materi system pencernaan. Pengembangan e-magazine dilakukan dengan menggunakan model ADDIE (Analysis, Design, Development, Implementation, dan Evaluation). Parameter dalam penelitian ini adalah kualitas e-magazine dan minat belajar. Pengujian minat belajar dilakukan dengan menggunakan angket minat yang diberikan pada peserta didik untuk kelas kontrol terdiri dari 36 orang peserta didik dan pada kelas eksperimen terdiri dari 36 orang peserta didik. Hasil pengembangan e-magazine berbasis AR relatif baik. Hal ini terlihat dari hasil validasi dengan kategori sangat valid. Berdasarkan aspek didaktis diperoleh skor 3,82 dengan kategori sangat valid, aspek konstruktif 3,85 dalam kategori sangat valid dan aspek teknis 3,78 dengan kategori sangat valid. Hasil penelitian menunjukkan bahwa penggunaan e-magazine berbasis AR meningkatkan minat belajar. Minat belajar memperoleh skor 0,342 dengan kategori tinggi. Dengan demikian, dapat disimpulkan bahwa penggunaan e-magazine berbasis AR sebagai media pembelajaran digital dapat digunakan dalam proses pembelajaran.
\end{abstract}

\section{A B S T R A C T}

Currently, the obstacles faced in learning process are found to be low student interest in learning. The main factor contributing to low student interest in learning is influenced by the lack of variety of learning media used by teachers in schools. The use of augmented reality (AR) in education is classified as an important research topic, although it is still being studied in its early stages. The purpose of this research was to develop learning media using e-magazine based on an AR to increase students' interest in learning. The developed e-magazine was carried out using model of ADDIE (analysis, design, development, implementation and evaluation). Parameters in this study was focused on the quality of e-magazine and students' interest in learning. Testing students' interest in learning was conducted by using a questionnaire and given directly to students. The experiments were carried out in the control class consisting of 36 students and the experimental class consisting of 36 students. Results of the study found that the development of AR-based e-magazines were obtained in relatively good category. This value was supported by the validation value found in the very valid category. Analysis on the didactic, constructive and technical aspects were obtained a score of 3,82,3,85 and 3.78, respectively, with a very valid category. The results also showed that the use of AR-based e-magazines could be increased students' interest in learning and students' interest in learning was obtained at a value of 0.342 in the high category. Thus, the use of AR-based e-magazines as digital learning media can be used in the learning process.

This is an open access article under the CC BY-SA license.

Copyright (C) 2021 by Author. Published by Universitas Pendidikan Ganesha.

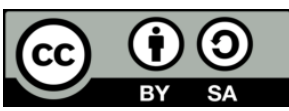

\section{INTRODUCTION}

Technological developments in the 4.0 revolution era can be applied in education as a learning tool, so sophisticated learning facilities can facilitate the learning process (Chang et al., 2021; Ghavifekr \& Rosdy, 2015; Zhang et al., 2021). The use of technology in learning can be designed to become a modern learning media that can be used in learning as a learning resource (Danniels et al., 2020; McGarr \& Gallchóir, 2021; Sert \& Boynueğri, 2017). Especially now that the world is hit by the COVID-19 outbreak, which requires every teacher to be able to use technology well for learning (Shah et al., 2020; Tang et al., 2021). Currently, teachers are 
required to use technology to teach so that learning can run smoothly. The benefit of using technology is that information or learning materials will be more easily accessible to make students more interested in learning (Ivanov et al., 2019; Summak et al., 2010). In addition, the use of technology can also make students more comfortable and not impressed or monotonous (Boyd, 2019; Shohel \& Kirkwood, 2012). This is because the delivery of information through changing technology looks more varied and modern.

Technology will make it easier for teachers to deliver learning materials to students (Bravo et al., 2015; Geng et al., 2019). One of the learning materials that require technical assistance is the human digestive system. Creating learning media by utilizing technology will make it easier for students to understand learning materials (Fakhruddin et al., 2019; Liang et al., 2011). The material about the digestive system in humans is one of the materials to study several events related to humans, such as the process of digestion of food, disorders, and diseases of the digestive system. The material of the human digestive system is classified as difficult material (Iqbal et al., 2017; Juannita \& Adhi, 2017). When viewed from the object and its material properties, the digestive system in the body cannot be observed directly. This contributes to students' difficulties in imagining the material being studied. Students cannot imagine the shape and location of the digestive organs in the human body, so they are not interested in studying it. This problem has an impact on students' lack of understanding so that student learning outcomes are low. The utilization of technology in the development of teaching materials can be applied in the learning process to assist students in learning (Komikesari et al., 2020; Noroozi \& Mulder, 2017; Rasmussen et al., 2020). zTherefore we need technology for manipulation and direct learning to integrate practical knowledge and skills in the form of spatial visualization (Dinayusadewi et al., 2020; Qumillaila et al., 2017). Spatial visualization can reduce students' cognitive load while working on assignments. One of the new technologies that can visualize learning is Augmented Reality, a new technology that is easy to use and relevant to adapt (Anuar et al., 2021; Lo et al., 2021). One of the learning media trends that have become a concern in education is media with Augmented Reality (AR) technology (Hincapie et al., 2021; Yavuz et al., 2021). Augmented Reality (AR) brings the meaning of technology that upholds virtual objects in real scenes by displaying additional information for incomplete information to the real world (Hamilton et al., 2021; Park et al., 2020).

The ability to display virtual objects into reality makes this technology the choice of educators in creating a more exciting and exploratory learning environment (Maijarern et al., 2018). Augmented Reality integration can be innovated and developed through learning media (Anuar et al., 2021; Lai et al., 2019). One of the learning media is an e-magazine equipped with $3 \mathrm{D}$ animation features that can help students in the learning process. Augmented reality makes the teaching and learning process more fun, more interactive in creating a learning experience. Augmented reality can increase students' learning motivation and contribute to better academic achievement. Interest in learning is an important factor in the learning process and is included as an internal factor that can affect student learning outcomes. If student interest in learning is low, it will cause low student learning outcomes (Arpan et al., 2016; Lauc et al., 2020). Testing the impact of using technology on student interest uses indicator 1). Feelings of pleasure, 2) Student involvement, 3) Attention, and 4) Student interest. Previous research stated that Augmented Reality is a technology that consists of a combination of 3D objects into a real environment using webcam media, either through a camera on a laptop or a cellphone (Chin \& Wang, 2021). Augmented Reality media is good to be applied in schools, and the results of the study show a positive response of students by 76\% (Chen et al., 2016; Khan et al., 2019). The use of Augmented Reality can increase students' learning motivation and contribute to better academic achievement. Augmented Reality makes the teaching and learning process more fun, more interactive in creating learning experiences (Rahman et al., 2021; Smith \& Friel, 2021). Various Augmented Reality applications have been developed, but research on the implications of Augmented Reality applications still lacks, mostly related to the impact of Augmented Reality on learning outcomes. Therefore, this study was conducted to see the effect of using Augmented Reality teaching materials by assessing student interest before and after using AR applications on the digestive system.

\section{METHOD}

The developed research is descriptive research and is in the form of research and development. This research is focused on developing an AR-based e-magazine using the ADDIE model. In previous studies, the analysis and design stages have been carried out and this research is carried out at the development stage. In previous research, the analysis and design stages have been carried out and are now focused on the development stage. The development of AR-based e-magazine media was inserted by various computer software such as blender, assemble and other supporting software. Development was carried out at the level of basic competence related to the concept of the human digestive system. The developed media was validated by four validators and consisted of media experts, material experts and two practical people. The validation was conducted by using a validation sheet which consists of didactic, construct and technical aspects. The total statements were 36 items. The analysis was conveyed using a quantitative descriptive method. This study is classified as a quasi- 
experimental with one group pretest-posttest design. The designed research was used one test group by implementing the product and followed by measuring posttest data.

The research was implemented at SMA Negeri 1 Pangkalan Kerinci, Riau. Samples were obtained through a sampling technique using purposive sampling. Determination of the sample was conducted by testing prerequisites and then determined by random sampling. The research sample consisted of 2 classes, namely the control class and the experimental class. Both classes of samples were treated using an AR-based e-magazine. Data was directly collected by observation, distributing questionnaires, and through cognitive tests. The description of data and research instruments for each stage is shown in Table 1.

Table 1. Research instruments arranged using the ADDIE model.

\begin{tabular}{|c|c|c|}
\hline $\begin{array}{c}\text { Development } \\
\text { stages }\end{array}$ & Data & Instruments \\
\hline Analysis & Observations and interviews & - Observation Questionnaire and interview \\
\hline Design & $\begin{array}{l}\text { AR-based e-magazine design draft } \\
\text { and learning device design }\end{array}$ & $\begin{array}{l}\text { - Software Usage: Corel Draw, } \\
\text { Photoscape, Blender, unity, Vuforia, } \\
\text { Assemblr }\end{array}$ \\
\hline Development & $\begin{array}{l}\text { - Validation results } \\
\text { - Practicality test } \\
\text { - Limited trial }\end{array}$ & $\begin{array}{l}\text { - } \quad \text { Making learning tools } \\
\text { - } \quad \text { educatidation sheet (material expert, } \\
\text { - } \quad \text { Practicality Questionnaire } \\
\text { - Student response questionnaire }\end{array}$ \\
\hline Implementation & $\begin{array}{l}\text { Field test: } \\
\text { - Interest to learn }\end{array}$ & - Learning Interest Questionnaire \\
\hline Evaluation & $\begin{array}{l}\text { This stage was carried out an overall } \\
\text { augmented reality-based e-magazines }\end{array}$ & evaluation of the achievement of using the \\
\hline
\end{tabular}

The e-magazine was validated by four validators consisting of material experts, education experts, media experts and teachers. The validation sheet was composed of several aspects such as didactic, constructive and technical aspects. There were 36 statements in the e-magazine validation sheet. he didactic instrument grid is about AR-based e-magazine material that is made according to basic competencies, indicators, learning objectives and easy-to-understand applications. For the constructive aspect, it must be able to explain identity, according to the correct Indonesian language rules, 3D animation helps learning. While the technical aspect describes the appearance of the letters used, the selection of colors so as to produce an attractive appearance and easy to use. The grid of validation sheets assessed by validators is summarized in Table 2 .

Table 2. Grid of validation sheet

\begin{tabular}{cccc}
\hline No & Assessment Aspect & Instrument Number & Number of Instruments \\
\hline 1. & Didactic & $1-14$ & 14 \\
2. & constructive & $1-13$ & 13 \\
3. & Technical & $1-9$ & 9 \\
\hline \multicolumn{2}{r}{ Total } & & 36 \\
\hline
\end{tabular}

Aspects of assessment were evaluated by the validator and made in the form of a rating scale. The used scale is in the form of a Linkert scale with a score of 1-4. The practicality test is carried out using a practicality questionnaire with assessment indicators consisting of appearance and language, attractiveness, and use. The practicality analysis uses a Likert scale by giving a score for each item the answers are very practical (4), practical (3), less practical (2), and not practical (1). Limited trials were conducted to see the practicality of the developed E-magazine. Data collection was carried out using a student response questionnaire to the developed E-magazine.

Testing interest in learning was conducted by using an interest questionnaire and given to students for the control class and the experimental class. The control class consisted of 36 students and the experimental class also consisted of 36 students.. The interest questionnaire consists of 30 statement items with 4 indicators of learning interst. Questionnaires were given directly at the end of the lesson. Analysis of the results of filling out 
the interest questionnaire was carried out by scoring each item in the filling out questionnaire. Furthermore, the percentage of students' motivational questionnaire scores were analyzed according to the criteria adapted from the Riduwan, (2007) assessment guideline.

\section{RESULT AND DISCUSSION}

\section{Result}

The results of the validation analysis on Augmented Reality-based e-magazines were found 3 aspects of assessment such as didactic, constructive and technical aspects (Önal \& Önal, 2021). Validation was carried out by 4 validators consisting of one material expert, one media expert, and two teachers. The overall AR-based emagazines that have been developed obtained an average score for the didactic aspect of 3.81 with a very valid category, the didactic aspect received a score of 3.82, then for the construction aspect the average score was 3.85. and for the technical aspect, the average score is 3.78 with each category being very valid. The developed AR-based e-magazine has been validated, and then tested on a limited basis to see the practicality of the developed e-magazine. The practicality test was reported to consist of three main aspects, namely appearance and language, attractiveness, and use. Practicality test was conducted on three respondents. Overall the average value of the practicality test was found to be 84.61 with a very practical category. Based on the aspect of appearance and language, an average score of 84.38 was obtained in very practical category.

A limited trial was conducted to determine the students' responses to the developed e-magazine. The response assessment was conveyed using student response questionnaires. 20 students gave the response questionnaire to the proposed e-magazine. The results of students' responses to Augmented Reality-based emagazines are that students think $86 \%$ (good) and 14\% (very good) are used in the learning process. The 3D animation on this AR-based e-magazine can enrich students' insights regarding the concepts of digestion and food substances being studied. The test of interest in learning was carried out using an interest questionnaire and was given directly to students for the control class and the experimental class. The control class consisted of 36 students and the experimental class also consisted of 36 students. An interest questionnaire was given at the end of the lesson. Overall interest in learning shows the results of student interest in learning in the control class before learning is in the sufficient category (69.8\%) and after learning in the sufficient category (73.4\%), while in the experimental class there is an increase in interest in learning after the use of e-magazine-based AR, namely from the sufficient category before learning (70.6\%) increased to a good category $(79.7 \%)$ after the learning process. The assessment of learning interest using a learning interest questionnaire consists of 4 indicators of learning interest assessment. Indicators of interest in learning consist of feelings of pleasure, interest, attention and student involvement. The results of the percentage of learning interest assessment for each indicator in the control class and experimental class after learning can be seen in Figure 1.

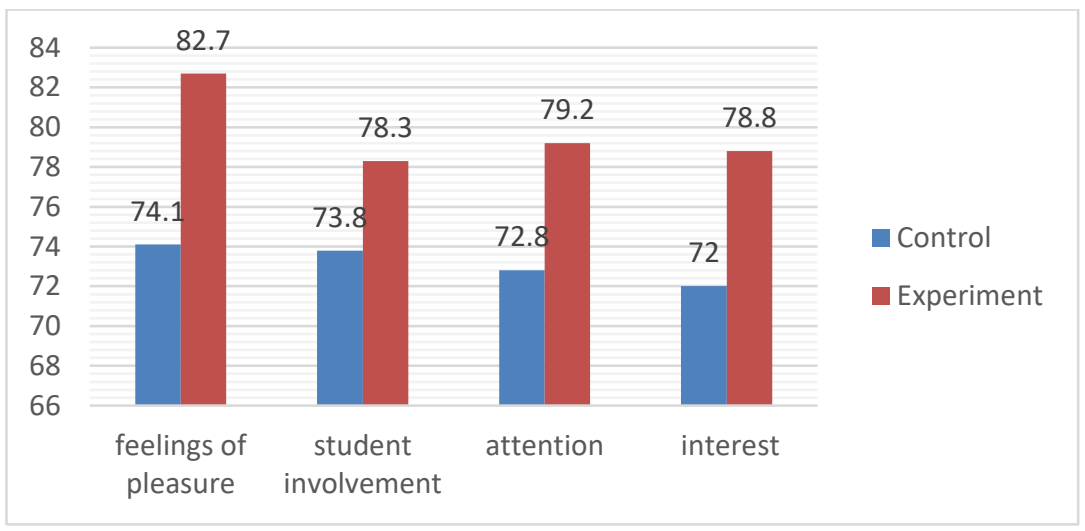

Figure 1. The percentage of interest in learning analyzed from a questionnaire in the control and experimental classes.

The increase in students' interest in learning could be seen from the four indicators of interest in learning (Figure 2). From the four indicators of interest in learning, it was found that the first indicator related to feeling happy in the experimental class got the highest score, namely the control class got a score of $74.1 \%$ while the experimental class got a score of $82.7 \%$ in the high category. The interest indicator in the control class got a score of $73.8 \%$ while the experimental class got a score of $78.3 \%$, the attention indicator in the control class got a score of $72.8 \%$ while the experimental class got a score of $79.1 \%$, and the involvement indicator in the control class got a score $72.0 \%$ while the experimental class got a score of $78.8 \%$. These results indicate that there is a difference in the average percentage for each indicator of interest in learning in the control class and the experimental class. 
After discussing the results of the interest in learning further description hypothesis test. Hypothesis testing was conducted to determine the difference in interest between students who were treated with AR-based e-magazines and those who did not use AR-based e-magazines. The hypothesis test carried out is the independent $t$ test with a significance of $=0.05$. The results of the $t$-test of learning interest found that the value of sig. ( 2 tails) was t-count 11.295 and t-table 0.36 , thus the significance result was $0.000<0.05$, then $\mathrm{H} 0$ was rejected and $\mathrm{H} 1$ was accepted. This means that the developed Augmented Reality (AR)-based e-magazine has an effect on students' interest in learning.

\section{Discussion}

Based on the results of the validation of the AR-based e-magazine, the results obtained are in a very valid category for didactic, construction, technical requirements and can be continued in use at the next stage. Didactic, construction and technical requirements are important requirements in the development of AR-based emagazines. The didactic requirements must follow the principles of effective teaching and learning in order to obtain good results and be able to attract the interest of students with 3D animations that are displayed (Koning et al., 2019; Sanchez \& Weber, 2019). The construction requirements for the development of the e-magazine have been completed with the identity and usage steps. The learning material in the e-magazine has the correct concept equipped with 3D AR animations that are clear and interesting to use so that it helps the learning process (Herbert et al., 2021; Kühl, 2021). Didactic requirements must follow the principles of effective teaching and learning, are: 1) can be used by students who are slow, moderate, or clever; 2) emphasize the process of finding concepts; 3) have a variety of stimuli through various media and student activities; 4) can develop social, emotional, moral, and aesthetic communication skills in children (Prastika et al., 2021; Selvianiresa \& Prabawanto, 2017). The didactic requirements of a product can bring up a stimulus by using tools and interacting with real objects to explore students' initial abilities. Construction requirements are aspects related to constructive requirements, namely the use of language, sentence structure, vocabulary, level of difficulty, and clarity. Technical aspects are complementary aspects that are also important in development. Technical requirements are requirements relating to writing, images, and appearance (Knoop-van Campen et al., 2020; Lauc et al., 2020).

The development of the AR-based e-magazines has been carried out on material of the human digestive system including organs, form, function, digestive system processes, analysis of food in the digestive system and diseases of the digestive organs. This AR-based e-magazine has also been revised several times, so that the resulting product can be used in the learning process and can be used as contextual learning. The digestive system in the e-magazine was obtained from the development equipped with a marker containing a 3D animation database as an aid in finding any organs that affect the digestive system. The use of AR allows virtual objects into the real environment to facilitate real time interaction (Dinayusadewi et al., 2020; Yusuf \& Widyaningsih, 2020). Media is a teaching material that serves to convey messages and information in learning (Noroozi \& Mulder, 2017; Rasmussen et al., 2020).Animation of 3D Augmented Reality could be observed in the developed e-magazine. This innovation was made to differentiate this e-magazine from the previous e-magazines. This innovation is also carried out to increase the attractiveness or interest of students to take part in learning. As a consequence, learning becomes easier to learn. In addition, $3 \mathrm{~d}$ animation can also add insight and make it easier for students to find and understand the concepts being studied. All designs are well structured and related to each other to produce better motivation from the students themselves (Bacca et al., 2018; Gopalan et al., 2016). Augmented Reality media can make it easier for students to learn and attract students' attention in learning (Bursali \& Yilmaz, 2019; Sahin \& Yilmaz, 2020).

AR can provide highly interactive experiences and can result in authentic learning activities and interactions. The factors that influence the emergence of interest in learning are 1) the lesson will attract students if there is a relationship between the lesson and real life, 2) the assistance provided by the teacher to his students in achieving certain goals, 3) the opportunity given by the teacher to students to play a role. active in the teaching and learning process, 4) the attitude shown by the teacher in an effort to increase student interest. The results of the study provide an overview of students' interests before and before the use of Augmented Reality integrated e-magazines. The results of the study found that the Augmented Reality Application could positively increase the interest of high school students. The student's interest was initially at a moderate level, however, using the Augmented Reality application, the student's interest increased to a higher level. This is because the use of Augmented Reality makes students' interest increase to a higher level. Students are more focused, confident, and satisfied with the e-magazine used. The study also found that the use of learning materials integrated with Augmented Reality is suitable for today. Therefore, it is recommended for teachers to master and maximize the use of Augmented Reality technology to ensure a better and effective learning environment. However, the results of this study were limited to the student system because the sample selection was objective and not random. 


\section{CONCLUSION}

The Augmented Reality-based e-magazine development has been analysed and has very good quality. Based on the results of analysis, the AR-based e-magazines can be used as digital media for learning, because it can make learning activities more interesting, efficient, and increase student interest. Something that interests and attracts attention will make students interested in learning.

\section{REFERENCES}

Anuar, S., Nizar, N., \& Ismail, M. A. (2021). The Impact of Using Augmented Reality as Teaching Material on Students' Motivation. Asian Journal of Vocational Education And Humanities, 2(1). https://doi.org/10.53797/ajvah.v2i1.1.2021.

Arpan, M., Sulistiyarini, D., \& Santoso, D. (2016). Effect of Motivation and Creativity on Students' Psychomotor Ability. Journal of Education, Teaching and Learning, 1(2). https://doi.org/10.26737/jetl.v1i2.42.

Bacca, J., Baldiris, S., \& Fabregat, R. (2018). Insights into the Factors Influencing Student Motivation in AR Learning Experiences in Vocational Education and Training. Psychol. https://doi.org/10.3389/fpsyg.2018.01486.

Boyd, L. (2019). Using Technology-Enabled Learning Networks to Drive Module Improvements in the UK Open University. Journal of Interactive Media in Education, 2019(1), 1-7. https://doi.org/10.5334/jime.529.

Bravo, E. R., Santana, M., \& Rodon, J. (2015). Information Systems and Performance: The Role of Technology, the Task, and the Individual. Behaviour and Information Technology, 34(3), 247-260. https://doi.org/10.1080/0144929X.2014.934287.

Bursali, H., \& Yilmaz, R. M. (2019). Effect of Augmented Reality Applications on Secondary School Students' Reading Comprehension and Learning Permanency. Computers in Human Behavior, 95. https://doi.org/10.1016/j.chb.2019.01.035.

Chang, H.-Y., Wu, H.-F., Chang, Y.-C., Tseng, Y.-S., \& Wang, Y.-C. (2021). The Effects of a Virtual Simulation-Based, Mobile Technology Application on Nursing Students' Learning Achievement and Cognitive Load: Randomized Controlled Trial. International Journal of Nursing Studies, 120. https://doi.org/10.1016/j.ijnurstu.2021.103948.

Chen, C. H., Chou, Y. Y., \& Huang, C. Y. (2016). An Augmented-Reality-Based Concept Map to Support Mobile Learning for Science. Asia-Pacific Education Researcher, 25(4). https://doi.org/10.1007/s40299-016-0284-3.

Chin, K.-Y., \& Wang, C.-S. (2021). Effects of Augmented Reality Technology in a Mobile Touring System on University Students' Learning Performance and Interest. Australasian Journal of Educational Technology, 37(1). https://doi.org/10.14742/ajet.5841.

Danniels, E., Pyle, A., \& DeLuca, C. (2020). The Role of Technology in Supporting Classroom Assessment in Play-Based Kindergarten. Teaching and Teacher Education, 88. https://doi.org/10.1016/j.tate.2019.102966.

Dinayusadewi, N. P., Ngurah, G., \& Agustika, S. (2020). Development of Augmented Reality Application as a Mathematics Learning Media in Elementary School Geometry Materials. Journal of Education Technology, 4(2), 204-210. https://doi.org/10.23887/jet.v4i2.25372.

Fakhruddin, Z., Amzah, A., \& Nurchalis, N. F. (2019). Technology-Based Teaching Material Development Training for Pre-Service Teachers to Improve Students' Learning Outcomes. NOBEL: Journal of Literature and Language Teaching, 10(1), 87-102. https://doi.org/10.15642/nobel.2019.10.1.87-102.

Geng, S., Law, K. M. Y., \& Niu, B. (2019). Investigating Self-Directed Learning and Technology Readiness in Blending Learning Environment. International Journal of Educational Technology in Higher Education, 16(1), 17. https://doi.org/10.1186/s41239-019-0147-0.

Ghavifekr, S., \& Rosdy, W. A. W. (2015). Teaching and Learning with Technology: Effectiveness of ICT Integration in Schools. International Journal of Research in Education and Science, 1(2). https://ijres.net/index.php/ijres/article/view/79.

Gopalan, V., Zulkifi, A. N., \& A., B. J. A. (2016). A Study of Students' Motivation Using the AR Science Textbook. AIP Conference Proceedings, 1. https://doi.org/10.1063/1.4960880.

Hamilton, D., McKechnie, J., Edgerton, E., \& Wilson, C. (2021). Immersive Virtual Reality as a Pedagogical Tool in Education: A Systematic Literature Review of Quantitative Learning Outcomes and Experimental Design. Journal of Computers in Education, 8(1). https://doi.org/10.1007/s40692-02000169-2.

Herbert, V. M., Perry, R. J., LeBlanc, C. A., Haase, K. N., Corey, R. R., Giudice, N. A., \& Howell, C. (2021). Developing a Smartphone App with Augmented Reality to Support Virtual Learning of Nursing 
Students on Heart Failure. Clinical Simulation in Nursing, 54. https://doi.org/10.1016/j.ecns.2021.02.003.

Hincapie, M., Diaz, C., Valencia, A., Contero, M., \& Güemes-Castorena, D. (2021). Educational Applications of Augmented Reality: A Bibliometric Study. Computers \& Electrical Engineering, 93. https://doi.org/10.1016/j.compeleceng.2021.107289.

Iqbal, M. M., Anra, \& Pratiwi. (2017). Pernerapan Augmented Reality sebagai Media Pembelajaran Virus dalam Mata Pelajaran Biologi Kelas X SMA. Jurnal Sistem Dan Teknologi Informasi (JUSTIN), 5(2). https://jurnal.untan.ac.id/index.php/justin/article/view/18515.

Ivanov, D., Dolgui, A., \& Sokolov, B. (2019). The Impact of Digital Technology and Industry 4.0 on the Ripple Effect and Supply Chain Risk Analytics. International Journal of Production Research, 57(3), 829846. https://doi.org/10.1080/00207543.2018.1488086.

Juannita, \& Adhi. (2017). Pengembangan Media Pembelajaran Sistem Pencernaan Manusia untuk Kelas 8 SMP dengan Fitur Augmented Reality Berbasis Android. Jurnal Pinter, 1(1). https://doi.org/10.21009/pinter.1.1.10

Khan, T., Johnston, K., \& Ophoff, J. (2019). The Impact of an Augmented Reality Application on Learning Motivation of Students, 2019, 1-14. Advances in Human-Computer Interaction. https://doi.org/10.1155/2019/7208494.

Knoop-van Campen, C. A. N., Segers, E., \& Verhoeven, L. (2020). Effects of Audio Support on Multimedia Learning Processes and Outcomes in Students with Dyslexia. Computers and Education, 150(February), 103858. https://doi.org/10.1016/j.compedu.2020.103858.

Komikesari, H., Mutoharoh, M., Dewi, P. S., Utami, G. N., Anggraini, W., \& Himmah, E. F. (2020). Development of E-Module Using Flip Pdf Professional on Temperature and Heat Material. Journal Of Physics: Conference Series, 1572(1). https://doi.org/10.1088/1742-6596/1572/1/012017.

Koning, B. B. de, Marcus, N., Brucker, B., \& Ayres, P. (2019). Does Observing Hand Actions in Animations and Static Graphics Differentially Affect Learning of Hand-Manipulative Tasks? Computers \& Education, 41. https://doi.org/10.1016/j.compedu.2019.103636.

Kühl, T. (2021). Prerequisite Knowledge and Time of Testing in Learning with Animations and Static Pictures: Evidence for the Expertise Reversal Effect. Learning and Instruction, 73. https://doi.org/10.1016/j.learninstruc.2021.101457.

Lai, A. F., Chen, C. H., \& Lee, G. Y. (2019). An Augmented Reality-Based Learning Approach to Enhancing Students' Science Reading Performances from the Perspective of the Cognitive Load Theory. British Journal of Educational Technology, 50(1), 232-247. https://doi.org/10.1111/bjet.12716.

Lauc, T., Jagodić, G. K., \& Bistrović, J. (2020). Effects of Multimedia Instructional Message on Motivation and Academic Performance of Elementary School Students in Croatia. International Journal of Instruction, 13(4), 491-508. https://doi.org/10.29333/iji.2020.13431a.

Liang, Y., Zheng, T., \& Wang, M. (2011). English Audio-Visual Teaching Mode and Its Teaching Environment Construction-Henan Institute of Science and Technology as the Example. 2011 International Conference on Multimedia Technology, 3050-3053. https://doi.org/10.1109/ICMT.2011.6001924.

Lo, J.-H., Lai, Y.-F., \& Hsu, T.-L. (2021). The Study of AR-Based Learning for Natural Science Inquiry Activities in Taiwan's Elementary School from the Perspective of Sustainable Development. Sustainability, 13(3). https://doi.org/10.3390/su13116283.

Maijarern, T., Chaiwut, N., \& Nobnop, R. (2018). Augmented Reality for Science Instructional Media in Primary School. 3rd International Conference on Digital Arts, Media, and Technology, ICDAMT. https://doi.org/10.1109/ICDAMT.2018.8376523.

McGarr, O., \& Gallchóir, C. Ó. (2021). Examining Supervising Field Instructors' Reporting and Assessment of Technology Use by Pre-Service Teachers on School Placement. Computers \& Education, 146. https://doi.org/10.1016/j.compedu.2019.103753.

Noroozi, O., \& Mulder, M. (2017). Design and Evaluation of a Digital Module with Guided Peer Feedback for Student Learning Biotechnology and Molecular LifeSciences, Attitudinal Change, and Satisfaction. Biochemistry and Molecular Biology Education, 45(1), 31-39. https://doi.org/10.1002/bmb.20981.

Önal, N. T., \& Önal, N. (2021). The Effect of Augmented Reality on the Astronomy Achievement and Interest Level of Gifted Students. Educ Inf Technol, 26. https://doi.org/10.1007/s10639-021-10474-7.

Park, K.-B., Choi, S. H., Kim, M., \& Lee, J. Y. (2020). Deep Learning-Based Mobile Augmented Reality for Task Assistance Using 3D Spatial Mapping and Snapshot-Based RGB-D Data. Computers \& Industrial Engineering, 146. https://doi.org/10.1016/j.cie.2020.106585.

Prastika, V. Y. A., Riyadi, R., \& Siswanto, S. (2021). Discovery and Core Learning Model toward Creative Thinking Viewed from Logical Mathematical Intelligence. Jurnal Aksioma, 10(1). https://doi.org/10.24127/ajpm.v10i1.3429.

Qumillaila, Susanti, B. H., \& Zulfiani, Z. (2017). Pengembangan Augmented Reality Versi Android sebagai Media Pembelajaran Sistem Ekskresi Manusia. Cakrawala Pendidikan, 34(1), 57-69. 
https://doi.org/10.21831/cp.v36i1.9786.

Rahman, A., Xi, M., Dabrowski, J. J., McCulloch, J., \& Arnold, S. (2021). An Integrated Framework of Sensing, Machine Learning, and Augmented Reality for Aquaculture Prawn Farm Management. Aquacultural Engineering, 95. https://doi.org/10.1016/j.aquaeng.2021.102192.

Rasmussen, E., Goddard, A. G., \& Bayer, D. K. (2020). Use of Electronic Learning Modules Can Improve Medical Trainee Knowledge Regarding Anaphylaxis Diagnosis and Treatment. Annals of Allergy, Asthma \& Immunology, 124(3). https://doi.org/10.1016/j.anai.2019.12.018.

Sahin, D., \& Yilmaz, R. M. (2020). The Effect of Augmented Reality Technology on Middle School Students' Achievements and Attitudes towards Science Education. Computers \& Education, 144. https://doi.org/10.1016/j.compedu.2019.103710.

Sanchez, C. A., \& Weber, K. (2019). Using Relevant Animations to Counter Stereotype Threat When Learning Science. Journal of Applied Research in Memory and Cognition, 8(4). https://doi.org/10.1016/j.jarmac.2019.08.003.

Selvianiresa, D., \& Prabawanto, S. (2017). Contextual Teaching and Learning Approach of Mathematics in Primary Schools. Journal of Physics: Conference Series, 895(1). https://doi.org/10.1088/17426596/895/1/012171.

Sert, N., \& Boynueğri, E. (2017). Digital Technology Use by the Students and English Teachers and SelfDirected Language Learning. World Journal on Educational Technology: Current Issues, 9(1), 24. https://doi.org/10.18844/wjet.v9i1.993

Shah, K., Arfan, M., Mahariq, I., Ahmadian, A., Salahshour, S., \& Ferrara, M. (2020). Fractal-Fractional Mathematical Model Addressing the Situation of Corona Virus in Pakistan. Results in Physics, 19, 103560. https://doi.org/10.1016/j.rinp.2020.103560.

Shohel, M. M. C., \& Kirkwood, A. (2012). Using Technology for Enhancing Teaching and Learning in Bangladesh: Challenges and Consequences. Learning, Media and Technology, 37(4), 414-428. https://doi.org/10.1080/17439884.2012.671177.

Smith, C., \& Friel, C. J. (2021). Development and Use of Augmented Reality Models to Teach Medicinal Chemistry. Currents in Pharmacy Teaching and Learning, 13(8). https://doi.org/10.1016/j.cptl.2021.06.008.

Summak, M. S., Bağlıbel, M., \& Samancioğlu, M. (2010). Technology Readiness of Primary School Teachers: A Case Study in Turkey. Procedia - Social and Behavioral Sciences, 2(2), 2671-2675. https://doi.org/10.1016/j.sbspro.2010.03.393.

Tang, Y. M., Chen, P. C., Law, K. M. Y., Wu, C. H., Lau, Y., Guan, J., He, D., \& Ho, G. T. S. (2021). Comparative Analysis of Student's Live Online Learning Readiness during the Coronavirus (Covid-19) Pandemic in the Higher Education Sector. Computers \& Education, 168, 104211. Https://Doi.Org/10.1016/J.Compedu.2021.104211.

Yavuz, M., Çorbacıŏlu, E., Başoğlu, A. N., Daim, T. U., \& Shaygan, A. (2021). Augmented Reality Technology Adoption: Case of a Mobile Application in Turkey. Technology in Society, 66. https://doi.org/10.1016/j.techsoc.2021.101598.

Yusuf, I., \& Widyaningsih, S. W. (2020). Implementing E-Learning-Based Virtual Laboratory Media to Students' Metacognitive Skills. International Journal of Emerging Technologies in Learning, 15(5). https://doi.org/10.3991/ijet.v15i05.12029.

Zhang, H., Daim, T., \& Zhang, Y. (Peggy). (2021). Integrating Patent Analysis into Technology Roadmapping: A Latent Dirichlet Allocation Based Technology Assessment and Roadmapping in the Field of. Blockchain. Technological Forecasting and Social Change, 167. https://doi.org/10.1016/j.techfore.2021.120729. 